\title{
News of the Profession
}

Organization of East Asian Studies in France

Contributed by Professor Paul Demiéville, Collège de France

\section{Ecole nationale des Langues orientales vivantes}

The basic school for learning Oriental languages in France is the National School for Living Oriental Languages in Paris (ELOV). It was created by a decree of the National Convention dated March 30, I795, as a continuation of the School for Junior Linguists (Ecole des Jeunes de Langues) created by Colbert under Louis XIV in I669 for the formation of a staff of interpreters in Near Eastern languages. It is independent of the University of Paris, and is placed under the direct control of the Ministry of National Education. Its aim is "to teach students to read, write, and speak the living languages of Eastern Europe, Asia, Oceania, and Africa, together with the geography, history, and institutions of the countries in which these languages are used." Instruction deals mainly with the living forms of the languages, starting from the elements of phonology, lexicology, grammar, and script; at present the object is to prepare students for scientific as well as practical careers, by providing a general initiation. For Chinese, kuo-yü is taught, with some wen-yen, mainly modern, in the second and third year courses. Each language is taught by a professor-there are two for some languages-and one or more native instructors (répétiteurs). A diploma may be obtained after a course of three years, the yearly and final examinations, oral and written, bearing both on languages and on history and geography.

As regards East Asia, there are chairs or lectureships for:

Cambodian (François MARTINI, since 1930; instructor: POU Saveros)

Chinese (Antoine BAZIN, I843-62; Stanislas JULIEN, 1863-70; Alexandre KLECZKOWSKI, ז871-86; Maurice JAMETEL, 1886-89; Gabriel DEVERIA, I889-99; Annold VISSIERE, I899-1930; Paul DEMIEVILLE, 1930-45; Léon JANKEL EVITCH, 1946-48; R. A. STEIN, 1949-52; LIN Li-wei, 1952-55; Robert RUHL MANN since 1955; present instructors: LI Tche-houa and LIANG Pai-tchin)

Modern Languages of India (Joseph GARCIN DE TASSY, $1828-78$; Julien VINSON, 1879-1921; Jules BLOCH, I921-37; Pierre MEILE since 1939; instructors: Bengali JAIN for Hindi, Nani SOUKRAMANIEN for Tamil, Mohammed Abdul MAJID for Urdu)

Japanese (Léon DE ROSNY, I868-1907; Joseph DAUTREMER, I907-3r; Charles HAGUENAUER, 1932-54; René SIEFFERT since 1954; instructor: MORI Arimasa)

Laotian (Marc REINHORN since 1949)

Malay-Indonesian (Edouard DULAURIER, 1844-62; Pierre FAVRE, I862-87; Aristide MARRE, I887-99; Alfred TUGAULT, I899-1906; Antoine CABATON, 1906-33; Véra SOKOLOFF since I943) 
Siamese (Maurice GARNIER, I872-99; Edouard LORGEOU, 1899-1925; Michel BREAL, 1926-27; Jean BURNAY, 1927-28; François MARTINI, 1929-4I; Sem SRIKASIBANDHA, 1942-49; George COEDËS, 1949-56; Robert LINGAT since I956)

Vietnamese (Abel DES MICHELS, 1871-73; Michel Duc CHAIGNEAU, 1873-88; Jean BONET, 1888-1907; Raymond DELOUSTAL, I910-22; Jean PRZYLU. SKI, 1923-3I; Emile GASPARDONE, 1932-47; Gustave MEILLON since 1948; instructor: PHAM-ngoc-Toan)

Geography, History, and Institutions of Far Eastern States (Guillaume PAUTHIER, 1872-80; Henri CORDIER, I881-I925; Marcel GRANET, 1925-40; René GROUSSET, 194I-52; Vadime ELISSEEFF, 1952-55; Nicole VANDIERNICOLAS since 1955)

At present Chinese attracts far more students than any other East Asian language. For the academic year 1956-57, II4 students matriculated for Chinese, of whom 79 took the examinations (first, second, and third years) in June 1957 (coming third in number after Russian: $66_{4}$ and 325, and Literary Arabic: 137 and 93).

The School has an important library open to students, who may take out books, and including books and periodicals both in Western and Eastern languages (about 2,000 works in Chinese).

\section{Université de Paris}

At the Faculty of Letters of the University of Paris (located, with the Faculty of Sciences, in the building known as the Sorbonne), there are at present:

Two chairs for indology: Indian Language and Literature, originally called Sanskrit and Comparative Grammar [i.e., Indo-European Linguistics] (Abel BERGAIGNE, I885-88; Victor HENRY, r888-1907; Alfred FOUCHER, 1907-36; Louis RENOU, I936-57; Armand MINARD since 1957) and Civilization of India and Southeast Asia (Louis RENOU, since 1957)

One for sinology (History of Chinese Civilization, Marcel GRANET, 1920-26; Chinese Language and Civilization, Jacques GERNET, since 1957)

One for japanology (Japanese Civilization, Maxime REVON, 1920-37; Japanese Language and Civilization, with a complementary course in Korean, Charles HAGUENAUER, since 1954)

The professorships are provided with posts of Readers (lecteurs) (Chinese: TCHEN Y-sia; Japanese: MORI Arimasa; Korean: LI Ogg).

For a short time up to 1955 there was a chair for the Archaeology of Southeast Asia, occupied by Pierre DUPONT; since his premature death, Jean BOISSELIER has been lecturing on the arts of the Far East at the Institute for Art and Archaeology of the University of Paris.

Lectures and tuition deal mainly with classical matters (Sanskrit, Literary Chinese, ancient history, classical literatures, etc.).

Among the various diplomas and degrees delivered by the University of Paris, the following are of interest for East Asian studies.

Five different Certificates of Higher Studies (certificats d'études supérieures) are necessary for obtaining the degree of Licence ès Lettres, some of them incompatible with some others. Among the numerous certificates authorized by the Faculty, the 
following are wholly or partly connected with East Asian studies: Chinese Civilization, Comparative Grammar of Classical Languages, Ethnology, General Linguistics, Indian Studies, Japanese Civilization, History of Religions.

The University Doctorate (Doctorat d'Université) requires the preparation of one thesis, to be publicly defended ("soutenue") before a jury of three professors. The thesis is similar in length and nature to a British Ph.D. or a German Dr. Phil. dissertation. This doctorate does not give access to university teaching in France, and is mostly pursued by foreigners, who have to stand a preliminary examination sometime before defending the thesis.

The Doctorate of Letters (Doctorat ès Lettres, also called Doctorat d'Etat, because it is delivered by the French State and recognized by it as qualifying for university teaching) requires the preparation of two theses (thèse principale and thèse complémentaire), to be defended before a jury of five professors. The theses are important affairs, requiring up to ten, twenty, thirty years of work; they are rarely attempted by foreigners.

For the preparation of both doctorates, candidates have to be directed by a professor, who reports to the Dean of the Faculty before the candidates are admitted to defend their theses. The subjects are free, but have to be registered in advance with the agreement of the professor acting as director.

To the University of Paris are attached University Institutes (Instituts d'Université), enjoying a certain measure of administrative autonomy, having their own premises (many outside the Sorbonne), and their own libraries (distinct from the general libraries of the various Faculties) open to students who have regularly registered at the institutes and to professors. These institutes organize regular or occasional lectures, apart from the courses of the Faculty, as well as meetings, receptions, etc. They are meant to co-ordinate the activities of the various educational institutions of Paris in which their respective disciplines are represented, and publish posting-bills in which these activities are graphically summarized for the discipline of each institute.

The Institute for Higher Chinese Studies (Institut des Hautes Etudes Chinoises, IHEC) was created in I926. Its first administrator was Marcel GRANET (I926-40), followed by Paul PELLIOT (1940-45) and Robert DES ROTOURS (since 1946); secretaries: Edouard MESTRE (1926-50), Louis HAMBIS (since 195I). The library is very considerable and has been described as "the best in Europe for sinological studies, not so much by its rarities as by its richness in both ancient and modern works, important for these studies" (HERVOUET). It is particularly rich in $t s^{\prime}$ ungshu (about 700 titles, the largest collection in Europe) and in fang-chih (about 500). It includes the large collection of Chinese books and periodicals formed in Peking at the Center for Sinological Studies (Centre d'études sinologiques), an institution which was created by Frenchmen on the spot during the Second World War, attached to the University of Paris after the end of the war, then closed in 1953 by order of the Chinese People's Government, which, however, allowed most of the books to be sent to Paris. Courses on sinological subjects are given at the Institute by professors from various institutions, and occasional public lectures by French and foreign scholars are provided; the courses prepare for the Certificate of Higher Studies in Chinese Civilization (a diploma of the Institute may also be obtained, but students now prefer the certificate, which is recognized as part of the Licence ès Lettres). The 
Institute's publications form the "Bibliothèque de l'Institut des Hautes Etudes Chinoises" (II volumes published from I930 to I957).

Here is a list of the courses and public lectures organized by the Institute for Higher Chinese Studies during the academic year $1957-58$ :

\section{Courses ( 18 hours each)}

Elements of Sinological Bibliography; Chinese Art (Louis HAMBIS)

Chinese Literature: (I) "Genres" and styles: Biographies from Shih-chi; Descriptions of the Capitals from Wen-hsüan (NGUYEN Phô)

(2) San-kuo-chih p'ing-hua and $K^{\prime} u n g-c h^{\prime}$ eng chi (Robert RUHLMANN).

Religions of China: (I) The development of religious thought in China between the Han and the Sui (Nicole VANDIER-NICHOLAS)

(2) Huai-nan-tzu, ch. I (Max KALTENMARK)

Elements of Social and Economic History: Sung history (Etienne BALAZS)

History of Modern and Contemporary China: The Manchurian and Mongolian questions (Georges DUBARBIER)

Public Lectures (I hour)

Excavations in the Swât valley (Giuseppe TUCCI, Rome)

The origins and nature of chattel slavery in China (E. G. PULLEYBLANK, Cambridge) Literature in New China (Jaroslav PRÖSKEK, Prague)

An aspect of the military history of medieval China: the defense of cities (Herbert FRANKE, Munich)

Japan as a center of sinological materials and studies (KANDA Kiichirō, Kyoto)

A walk in the Chinese cities of the rath and I 3 th centuries (Jacques GERNET)

A Chinese novel: The Three Kingdoms (Robert RUHLMANN)

The actuality of Marco Polo (Louis HAMBIS)

The main themes of Chinese thought (Max KALTENMARK)

The Institute for Indian Civilization (Institut de Civilisation indienne, ICI) was created in 1927 and has been presided over by Emile SENART (1927-28), Alfred FOUCHER (1928-38), Louis RENOU (since 1938; present secretary: Anne-Marie ESNOUL). Its status and organization are similar to those of the Institute for Higher Chinese Studies. It possesses a large library for indology, including the personal collections left by Emile SENART (d. 1928), Sylvain LEVI (d. 1935), Louis FINOT (d. 1935). There is a collection entitled "Publications de l'Institut de Civilisation indienne" (about 8 volumes have come out up to 1958 ).

An Institute for Japanese Studies (Institut d'Etudes japonaises) is at present in the course of reorganization under the direction of Professor Charles HAGUENAUER.

The three Institutes of the University of Paris mentioned above are to be regrouped in the near future in a large building recently acquired by the University of Paris outside the Sorbonne (near the Musée Guimet), where they will have ample facilities for the expansion of their libraries, offices, and premises for teaching, research, and meetings.

\section{Ecole pratique des Hautes Etudes}

The Practical School for Higher Studies (EPHE), created in 1868 with the aim of "adjoining to theoretical teaching practical exercises apt to strengthen and extend it," is administratively and scientifically independent of the University of Paris, though most of its premises are housed within the Sorbonne. It comprises at present six 
sections: (I) Mathematical Sciences, (2) Physical and Chemical Sciences, (3) Natural Sciences, (4) Historical and Philological Sciences (these four go back to I868), (5) Religious Sciences (1889), and (6) Economic and Social Sciences (1947). Teaching is of the seminar type; it is entrusted to Directors of Studies (directeurs d'études), who initiate advanced students into the techniques of research and direct them in their work by means of "practical exercises," pursued in common around a table without formality. Students may register without any condition of age, nationality, or previous degree or diploma; after one year, they may be proposed by the Directors of Studies for titularization as regular students (élèves titulaires). The School delivers a diploma conferring the title of "élève diplômé de l'Ecole Pratique des Hautes Etudes," which is highly appreciated in France (rather above the University Doctorate). It is granted after presentation of a thesis embodying original research; a report on the thesis is made by two Directors of Studies, different from the one who has directed its preparation, before the Council of Directors of Studies which may pronounce the acceptance of the thesis after hearing and discussing the report.

Sections 4 and 5 each publish collections entitled "Bibliothèque de l'Ecole Pratique des Hautes Etudes" (Section 4: 308 volumes from 1868 to 1957; Section 5: 88 volumes from I 889 to 1957; several volumes concern East Asia). All the sections also publish Annual Reports ("Annuaires") containing documents, chronicles, necrologies, and summaries of each Director of Studies concerning his and his students' work and publications during the current year, often with one or two original articles by the Directors of Studies.

Section 6 , recently created, has started about five series of publications. Books concerning East Asia have been published already, or are in the press, in the series entitled "The Overseas World" (Le Monde d'Outre-Mer), a publication of an annex of the 6th section called the Center of Historical Research (Centre de Recherches historiques). These include:

Louis DUMONT, Une sous-caste de l'Inde du Sud: organisation sociale et religion des Pramalai Kallar, 1957

Suzanne VREEDE, L'émancipation de la femme indonésienne (in press)

Yves HERVOUET, Catalogue des monographies locales chinoises dans les bibliothèques européennes, 1957

HERVOUET, LAND, PÉLISSIER, Catalogue des périodiques chinois dans les bibliothèques européennes (in press)

FUHRER-HAIMENDORF, Bibliographie de l'anthropologie culturelle et sociale aux Indes (in press)

Contributions to Indian Sociology, Nos. 1-2, 1957-58

(The above are all published by Mouton \& Co., The Hague.)

The Center of Historical Research also publishes a new polycopied review, Cahiers d'Extrême-Orient (Far Eastern Papers)-Vol. I, No. I, is in press-and the occasional publications of the "Sung Project," an international undertaking headed by Etienne BALAZS, designed to produce a Handbook for the Sung Dynasty which will include biographical, bibliographical, and general articles concerning all aspects of Sung-dynasty history. Numerous Bibliographical Cards have already been published, as well as a Geographical Guide (Hope WRIGHT), a list of Official Titles (E. A. KRACKE), and a map of the important Economic Centers of the Southern Sung 
(Etienne BALAZS); an index of the Sung hui-yao (E. BALAZS, Colette PATTE) is in press.

The Center of Historical Research houses the project headed by Vadime ELISSEEFF which plans to produce a repertory of Sino-Japanese "Material Culture," that is, of that part of culture which can be described visually and not in writing, such as architecture, costume, furniture, etc. The first product of this project, now ready for publication, is a set of maps of Lin-an (Hang-chou) during the Southern Sung, including indications of all important centers of activity in the capital (temples, imperial palaces, administrative buildings, commercial establishments, bordellos, etc.). A collection of books and periodicals concerning modern China is also being formed at Section 6.

East Asian studies are abundantly represented in Sections 4, 5, and 6 of the Practical School for Higher Studies, in which many of the most illustrious French orientalists have been trained or have taught. Here is a list of Directions of Studies now extant in these three Sections, with the names of the Directors of Studies and their programs for the academic year $1957-5^{8}$ :

\section{Section 4 (Historical and Philological Sciences)}

\section{History}

Civilization and Languages of Upper Asia (Louis HAMBIS): ( $\mathrm{I}$ ) Chinese and Mongol texts concerning the history of the Mongols after the downfall of the Mongol dynasty of China; (2) Decipherment of Mongol inscriptions of the 18 th century and examination of a pentaglot Buddhist vocabulary of the same period

\section{Philology}

Comparative Grammar (Armand MINARD): (1) Indo-European antiquities; (2) Vedic problems

Sanskrit (Louis RENOU): (I) Explanation of Vedic texts; (2) Explanation of grammatical texts in Sanskrit

Indochinese Linguistics (François MARTINI, temporary course): (I) Explanation of Burmese texts; (2) Questions concerning Indochinese linguistics and explanation of texts

Indian Philology (Jean FILLIOZAT): (1) Explanation of Sanskrit and Pāli Buddhist texts; (2) Explanation of an Upanișad

Vietnamese Philology (Maurice DURAND): (I) History and literary history of Vietnam; (2) Explanation of classical texts in Nôm and Quôc-ngu

Cambodian Epigraphy (AU Chhieng, temporary course).

Tibetan Philology (Marcelle LALOU): (1) Elements of classical Tibetan; (2) Tun-huang manuscripts dealing with omens

Buddhist Philology (Paul DEMIÉVILLE and André BAREAU): (I) Study of texts dealing with the problem of the person in ancient Buddhism; (2) Some minor texts of the Sarvāstivadin: introduction to the study of the Abhidharma; (3) Elements of Pâli: grammar and exercises

\section{Section 5 (Religious Sciences)}

Comparative Religions of the Far East and Upper Asia (R. A. STEIN): (I) Practical researches on Chinese popular religion; (2) Tibeto-Mongol religious folklore

Religions of China (Max KALTENMARK): (1) Lao-tzu in the Taoist religion; (2) The commentaries of the Tao-te ching 
Religions of Korea and Japan (Charles HAGUENAUER): Research concerning the beliefs and religious institutions of Japan from the 8th to the 12 th centuries, according to Japanese, Chinese, and Korean texts

Religions of Southeast Asia (Paul LEVY): (I) The religious value of the architectural disposition of Buddhist sanctuaries in Southeast Asia; (2) Sacrifice among the ProtoIndochinese

Religions of India (Olivier LACOMBE): (1) Explanation of the Arthaśästra; (2) Research on Buddhist Yoga

Comparative Study of the Religions of the Indo-European Peoples (Georges DUMÉZIL): (I) Explanation of Latin and Germanic texts concerning religion; (2) Questions of methodology and examination of recent publications

\section{Section 6 (Economic and Social Sciences)}

Economy and Society of Ancient China (Jacques GERNET): Daily life in the Sung period; Practical exercises

The Institutions of Imperial China (Etienne BALAZS): Problems of agrarian history; Research on the Sung land system; Studies on documents and direction of work

Art and Material Culture of the Sino-Japanese World (Vadime ELISSEEFFF): The diffusion of bronze in East Asia; Main results of archaeological excavations

History of Modern Japan (Serge ELISSEEFF): Japanese society of the Tokugawa ( I60or868), its intellectual and political aspects; Study of texts and documents

History of Modern China (Alexis RYGALOFF): The legal entity in China; Explanation of texts

Economic History of the Contemporary Far East (Jean CHESNEAUX): Research on industrial sociology and the history of the working movement in 2oth century China; Explanation of texts concerning the history of the working movement in 20 th century China

Sociology of India (Louis DUMONT, now in India for field-work)

Donald HOLZMAN (chargé de conférences): Shen Kua (1031-95) and his Meng-ch'i pitan

\section{Collège de France}

The origins of the Collège de France (also independent of the University of Paris) go back to $153^{\circ}$, when it was created by François I in order to teach the new disciplines of the Renaissance which had no place in the University of Paris. It is the highest institution in France for advanced teaching and research, and includes the most authoritative names of French science and scholarship. No degree is required to be eligible for a professorship. The titles and subjects of the chairs may be changed whenever there is a vacancy. The courses are public and open to all; there is no registration, no tuition, no examination; no titles, no diplomas are conferred. The professors (now 49 in number, 16 for the sciences, 33 for the humanities) present their current personal research and its results in public lecture courses (from 20 to 30 hours a year), which have to be entirely new every year. In these respects the Collège de France differs both from a university, where regular courses on definite subjects are maintained for the instruction of students, and from such institutions as the French National Center for Scientific Research (or the Institute for Advanced Study of Princeton), which are devoted to pure research without any teaching obligation.

The chairs for orientalism are the oldest in the Western world (Hebrew, 1530; Arabic, 1587; Chinese and Sanskrit, 1814). As regards East Asia, there are at present four chairs: 
Chinese Language and Literature (originally Chinese and Tartar-Manchu Languages and Literatures: Abel-REMUSAT, I814-32; Stanislas JULIEN, I832-73; Marie D'HERVEY DE SAINT-DENYS, 1874-92; Edouard CHAVANNES, I893-1918; Henri MASPERO, I92I-45; Paul DEMIÉVILLE since 1945). Titles of the lectures for the academic year 1956-57: (r) The Ch'an School; (2) Tun-huang texts of vulgar literature

Languages and Literatures of India (originally Sanskrit Language and Literature: Léonard DE CHEZY, I814-32; Eugène BURNOUF, 1832-52; Edouard FOUCAUX, I862-94; Sylvain LEVI, I894-1935; Jules BLOCH, I937-51; Jean FILLIOZAT since I95 I). Lectures 1956-57: (1) The external relations of Indian civilization; (2) Tamil religious texts

Indochinese History and Philology (Louis FINOT, I920-30; Jean PRZYLUSKI, I93I-44; Emile GASPARDONE since 1946). Lectures 1956-57: (I) The Nam ong mông luc [Dreams of the Old Southerner]; (2) Szu-ma Hsiang-ju among the Barbarians

Civilizations of the Far East (Paul MUS, since 1946). Lectures I956-57: Plastic and semantic symbolism in the archaeology of India and Southeast Asia

The "Annuaire du Collège de France" (57 volumes I90I-57) contains a general chronicle and reports of the professors on their work, publications, and missions, with summaries (fully detailed in recent years) of their lectures during the current year. The library of the Collège de France, open to professors only, includes valuable collections of books and periodicals concerning East Asia, some in East Asian languages.

\section{Ecole du Louvre}

The Ecole du Louvre, located within the Louvre Museum, was created in 1882. In it the history of art, archacology, epigraphy, and museology are taught, and students are prepared for research in these fields and for work in museums. There are Free Students (élèves libres), who may obtain an Ordinary Diploma (Diplôme de l'Ecole du Louvre), and Acknowledged Students (élèves agréés), who have to hold a university degree or pass an entrance examination, and may obtain a Higher Diploma (Diplôme de la Section Supérieure de l'Ecole du Louvre), giving access to official posts in French museums. Both diplomas require attendance during three years and the preparation of a thesis to be publicly defended. There is a chair for Archaeology and Arts of India and Outer India (Indochina, Indonesia, Indian Central Asia), at present held by Philippe STERN, and a chair for History of the Arts of the Far East, held by Madeleine PAUL-DAVID. Furthermore nine lectures each year are devoted to the arts of India, China, and Japan within the course on General History of Art which is compulsory for all students, and all the examinations include questions, both oral and written, concerning the arts of East Asia. A library is attached to the Ecole du Louvre.

\section{Institut d'Êtudes politiques and École nationale d'Administration}

The Institute for Political Studies of Paris, a private institution subsidized by the government, better known under its former name Ecole des Sciences Politiques, gives a course on modern China every other year. It was taught formerly by such scholars as Henri MASPERO and Jean ESCARRA; in $195^{6-57}$ the lecturers were Etienne BALAZS, Jean CHESNEAUX, and Vadime ELISSEEFF. The National School of Administration, which prepares for higher posts in the French administration, also 
provides irregular courses on contemporary questions concerning East Asia; Roger LEVY has lectured on the Far East, Tibor MENDE on India, etc.

\section{Centre de Hautes Études administratives sur l'Afrique et l'Asie modernes}

The Center for Higher Administrative Studies on Modern Africa and Asia (formerly called Centre de Hautes Etudes d'Administration musulmane) was created about I935 to provide instruction for members of the civil service in Overseas France and for officers of the French Army. There is an Asian Section, directed by Roger LEVY, in which quarterly courses are given on the Far East (Roger LEVY), Southeast Asia (George COEDĖS), India (Pierre MEILE), etc.

\section{Société Asiatique}

The Asiatic Society of Paris, founded in 1822 when Oriental studies began to develop in the West, is a private association of a learned character, numbering at present about 400 subscribing members and 24 honorary members, and whose activities cover the whole of Asia and part of Africa. It holds monthly meetings and publishes the Journal Asiatique (now in its I 36 th year) and other non-periodical publications, such as the recent series of "Cahiers de la Société Asiatique" (I4 volumes up to 1957). Candidates to membership have to be presented by two members and admitted by the Council of the Society. The presidents were successively Antoine SILVESTRE DE SACY (1822-29), Abel-REMUSAT (1829-32), Amédée JAUBERT (1834-47), Joseph REINAUD (I847-67), Jules MOHL (I867-76), Joseph GARCIN DE TASSY (1876-78), Adolphe REGNIER (1879-84), Ernest RENAN (1884-92), Casimir BARBIER DE MEYNARD ( $1892-1908$ ), Emile SENART (1908-28), Sylvain LEVI (1928-35), Paul PELLIOT (I935-45), Jacques BACOT (I946-5r); now Charles VIROLLEAUD. The Société Asiatique possesses an important library, open to members who can freely borrow books and have access to the shelves; it contains about 2,000 Chinese works, including the personal collections left by Edouard CHAVANNES (d. Igr8) and Henri MASPERO (d. I945); the indological collection of Alfred FOUCHER (d. 1952) was also bequeathed to the Society.

\section{Centre national de la Recherche scientifique}

The National Center for Scientific Research (CNRS), created in 1939 as a continuation of similar organizations previously in existence, is under the control of the Ministry of National Education. Its objective is "to develop, orient, and co-ordinate scientific research of every order." It provides subsidies for Researchers (chercheurs), Technical Assistants (collaborateurs techniques), materials, publications, and missions. It includes two Classes, one for Mathematical, Physico-Chemical, Biological, and Natural Sciences, one for Human Sciences. The latter is formed of seven Groups subdivided into twelve Sections, each of which is directed by a Section Committee of twelve members. The members of all Section Committees form the National Committee for Scientific Research (Comité national de la Recherche scientifique), headed by a Directing Committee (Directoire) of twenty-one members, with one Director and two Subdirectors, one for each Class.

Several of the Groups for Human Sciences, such as Group 7 (Anthropology, Prehistory, and Ethnography), Group 9 (Linguistic, Philological, Literary, and Musical Studies), Group II (Sociology and Social Psychology), Group I2 (Historical Studies), 
Group I3 (Philosophy), subsidize research staff and materials for the development of research concerning East Asia. There are at present two or three scores of Researchers and Technical Assistants receiving scholarships or subsidies in this field. Scholarships are not permanent, but have to be renewed every year or every second, third, or fifth year according to their various grades. The CNRS also subsidizes practically all French monographs and serials of a scientific character, besides having its own series of publications, some of which are expected to include, in the near future, works concerning East Asia. Its Documentation Center (Centre de Documentation) publishes a Bibliographical Bulletin (Bulletin signalétique), one part of which (quarterly) deals with international publications concerning Philosophy and Human Sciences.

\section{Museums}

The Musée Guimet was created by Emile GUIMET, an industrialist from Lyons who was interested in the history of religions and traveled in the Far East. It was first organized in Lyons in 1879 under the name Museum for the History of Religions, then moved to Paris (1889) where it became government property; it is now one of the National Museums. Emile GUIMET was director until his death in I9r8. The keepers were L. DE MILLOUÉ (up to ig06), Alexandre MORET (igo6-23), Joseph HACKIN (I923-4I), Georges SALLES (I94I-44), René GROUSSET (I94453 ); there are at present a Chief Keeper (conservateur en chef), Philippe STERN, and a Keeper (conservateur), Jeannine AUBOYER.

The Musée Guimet is devoted to the arts of East Asia, from Afghanistan and India to Central Asia, Tibet, Southeast Asia, and the Far East, including all the Central Asian and Far Eastern collections formerly kept in the Musée du Louvre, and the collections procured by official missions. It organizes many temporary exhibitions and public lectures which have a large attendance. It publishes a number of series of books, such as the "Annales du Musée Guimet," "Bibliothèque d'études," "Bibliothèque de diffusion," "Recherches et documents d'art et d'archéologie," and patronizes periodicals like Arts Asiatiques (quarterly, since 1954, a continuation of Revue des Arts Asiatiques, 1924-42) and Revue de l'Histoire des Religions (quarterly, since I880). There is a large library, the best in France (and probably in Europe) for the study of the arts and archaeology of East Asia, carefully kept up to date and particularly rich in Japanese books and periodicals, with a smaller collection of Chinese books; collections of photographs, films, musical records, etc.

The Musée Cernuschi is located in the former "hôtel" (mansion) of Henri CERNUSCHI, an economist and collector of Italian origin who traveled in the Far East and bequeathed his house and collections to the City of Paris in I 896 . It specializes in Chinese and Japanese art. The first keeper was Henri D'ARDENNE DE TIZAC (1896-1932), followed by René GROUSSET (1933-53); at present Vadime ELISSÉEFF is Chief Keeper, with Madeleine PAUL-DAVID as Adjunct Keeper. Temporary exhibitions of ancient and modern Chinese and Japanese art are frequently organized. A library is in course of development.

\section{Bibliothéque Nationale}

Apart from the special libraries which have been mentioned above, the National Library of France includes very important collections of books, periodicals, and manuscripts concerning East Asia. Printed books and periodicals in Western languages 
are mostly kept in the Département des Imprimés, while those in Eastern languages, either printed or manuscript, are kept in the Département des Manuscrits, under care of the head of the Cabinet Oriental, Marie-Roberte GUIGNARD. Borrowing is not authorized. A special reading room for orientalism, with reference works and current periodicals, is to be opened soon, apart from the general reading room of the Département des Manuscrits.

There are considerable collections of Indian and Indochinese manuscripts. Descriptive catalogues of the Sanskrit, Pāli, Indochinese, and Indonesian manuscripts have been published (Antoine CABATON, 4 volumes, I907-I2; Jean FILLIOZAT, I volume, I94I; AU Chhieng, I953); also a Catalogue (now antiquated) of Chinese, Korean, and Japanese books (Maurice COURANT, 8 volumes, I900-I2). The collection of Chinese books is by far the largest in France (about 15,000 works), with the largest collection of fang-chih in Europe (about 650). The Japanese collection has been considerably enlarged in recent years. These two collections are being regularly kept up to date by official international exchanges and by acquisitions. There are good catalogues on cards.

The collection of manuscripts from Tun-huang, acquired by Paul PELLIOT in rgo8, is particularly famous. Apart from the Sanskrit, Khotanese, Sogdian, Kuchean, Agnean, and Turkish manuscripts, which have been either described, published, or translated, a complete catalogue of the Tibetan manuscripts is in course of publication by Marcelle LALOU (Inventaire des manuscrits tibétains de Touen-houang conseryés à la Bibliothèque Nationale, 2 volumes published, 1939-50, describing I,292 manuscripts); she has also published or translated many of the manuscripts. The richest fund is that of Chinese manuscripts (2,709 numbers). A careful material restoration of these manuscripts has been undertaken since the death of Pelliot by the experts of the restoration service of the Library, and a general microfilm is being made, a long and delicate work which will make possible the printing and distribution of copies without endangering the original manuscripts by frequent handling of the rolls. A complete and detailed catalogue of the Chinese Tun-huang manuscripts has been for several years in course of preparation with the help of the National Center for Scientific Rescarch; the first volume, by Jacques GERNET and WU Chiyu, desciibing $5^{\circ 0}$ manuscripts, is in press. A collection of facsimiles, with translations or introductions, will also be included in the publications of the National Center for Scientific Research; one volume, containing the remains of a lost Taoist work of the T'ang dynasty, is now being printed. A Buddhist scroll with painted illustrations has been beautifully published already (Nicole VANDIER-NICOLAS, Säriputra et les six Maitres d'erreur, Paris, Imprimerie Nationale and Librairie orientaliste Paul Geuthner, 1954). Other Tun-huang manuscripts have been published in various collections entitled "Mission Pelliot en Asie Centrale" (two series, $4^{\circ}$ and $8^{\circ}$, 9 volumes published, Librairie orientaliste Paul Geuthner and Imprimerie Nationale, 19r4-54), "Manuscrits de Haute Asie conservés à la Bibliothèque Nationale de Paris (Fonds Pelliot)" (4 volumes published, Société Asiatique, I954-57), "Annales du Musée Guimet, Bibliothèque d'Etudes," etc.

\section{Provincial Universities}

Outside Paris, there are at the University of Lyons a chair for indology and a chair for sinology. (Lyons is the center of the silk trade in France and has always 
been interested in China.) The chair for Sanskrit and Comparative Grammar (=Indo-European comparative linguistics) was created in I9II and has been occupied by Félix LACOOTE (I9II-25), Louis RENOU (I925-29), Armand MINARD (1929-57); it is now held by Gisèle MANESSY (since 1957). The chair for Chinese, created in 1900, has been occupied by Maurice COURANT (1900-35) and Georges DUBARBIER (since 1935). The University includes in its program for the Licence ès Lettres the following Certificates of Higher Studies: Indian Studies, Chinese Studies, Languages and Literatures of the Far East, Civilization of the Far East.

To the chair for Chinese is attached a collection of Chinese books and periodicals formerly belonging to the Franco-Chinese Institute (Institut franco-chinois de Lyon), which played an important part in the education of Chinese students in France from 192I to 1947. This institute had been founded by agreement between the French and Chinese governments and was financed by funds from the Boxer Indemnity. It numbered up to 130 Chinese students, who were first trained at the Franco-Chinese University in Peking and then came to Lyons where they enrolled in the Faculties of Law, Letters, Medicine, and Sciences, or at the School of Fine Arts (Conservatoire des Beaux-Arts de Lyon). This institute was closed in 1947; the Franco-Chinese University has also ceased its activity.

At the University of Lille, Professor Olivier LACOMBE, a specialist in Indian philosophy, has held a chair for History of Philosophy and Comparative Philosophy since 1947. He devotes about one third of his lectures to Indian philosophy, also teaching the elements of Sanskrit.

Since 1955 Mlle FUGIER, lecturer in Latin at the University of Strasbourg, also teaches elementary Sanskrit as a complementary course. A lectureship in indology had been created for Sylvain LEVI at the University of Strasbourg after the First World War (1919-20); he was succeeded for some time by G. COURTILLIER.

\section{École française d'Extrême-Orient}

The French School of the Far East (EFEO) was created at Saigon in 1898 with the following aims: "(I) To work at the archaeological and philological exploration of the Indochinese Peninsula and to promote by every means the knowledge of its history, monuments, and languages; (2) to contribute to the scholarly study of the neighboring regions and civilizations (India, China, Japan, Indonesia, etc.)." During half a century it had its center and library-the best special library for East Asian studies during the first quarter of the present century-at Hanoi, while placed under the scientific control of the French Academy for History and Philology (Académie des Inscriptions et Belles-Lettres, one of the five academies forming the Institut de France). Former directors were Louis FINOT (1898-1904 and 1920-26), Alfred FOUCHER (1904-08), Claude-Eugène MAITRE (I908-20), Léonard AUROUSSEAU (1926-29), George COEDÈS (1929-47), Paul LEVY (1947-50), Louis MALLERET $\left(195^{0}-5^{6}\right)$.

Since the Second World War, the central direction has been transferred to France (present director: Jean FILLIOZAT), while local research centers have been established at Hanoi, Saigon, Phnompenh, and Vientiane, in agreement with the various governments concerned; permanent missions are also maintained in India, Indonesia, and Japan, and it is hoped that further centers or missions may be established in the future in other countries of East Asia such as China. The new status of the School, 
making it a purely French institution (like the French Schools at Athens, Rome, etc.) placed under the administrative control of the Ministry of National Education, while maintaining the scientific control of the Académie des Inscriptions et Belles-Lettres, has been for some years in the course of discussion with the various departments of the French government and will soon be submitted to the Parliament for approval. Since their accession to national independence the Indochinese governments have assumed the services of protection and conservation of historical monuments in their respective countries, formerly in charge of the School. By agreement with some of these governments (Cambodia in particular), the School provides them with technical assistance for archaeological conservation and exploration, while it is granted privileges for excavations.

The scientific staff of the School numbers at present about fifteen members, residing in the various local research posts or in France. The office of the central direction is in Paris; an Administrative Council (now presided over by Jacques BACOT) holds its meetings at the Académie des Inscriptions et Belles-Lettres. Missions may be granted to members of the School or to other scholars. In recent years ethnographical research has developed to an extent which was not foreseen when the school was created at the beginning of the century.

The School publishes a yearly Bulletin (BEFEO, 48 volumes r9or-57), besides a series of "Publications" ( 39 volumes I900-56), a "Library" ("Bibliothèque de l'EFEO," 2 volumes I902-53), a series of "Archaeological Memoirs" (8 volumes r926-32), a collection of "Texts and Documents on Indochina" (Io volumes I932-54); there is also a collection of independent publications ("Publications hors-série de l'EFEO," 20 volumes $190 \mathrm{I}-58$ ), and other publications have been sponsored by the School.

\section{Maison Franco-Japonaise}

The Franco-Japanese House at Tokyo, created in 1926, is a joint French and Japanese institution, controlled by the Ministries of Foreign Affairs of both countries and aimed at better mutual understanding between them on a high cultural level. The Directors have been orientalists (Alfred FOUCHER, I926; Sylvain LEVI, 1926-28; Paul DEMIÉVILLE, I929-30; Joseph HACKIN, I930-33; Louis RENOU, I955-57), a historian (Frédéric JOƯON DES LONGRAIS, 1939-46), jurists (Léon JULLIOT DE LA MORANDIÈRE, 1933-36, Léon MAZEAUD, 1936-39; René CAPITANT since I957). Two or three posts of residing members (pensionnaires) are reserved for young orientalists who may complete in Japan, during two, three, or more years, their training in japanology or sinology. Temporary missions are given to eminent representatives of French culture, sometimes orientalists.

The Maison Franco-Japonaise publishes a Bulletin (BMFJ, 40 volumes 1927-57) and a collection of "Publications" (ro volumes r928-54) dealing with the cultures of East Asia, chiefly Japan.

\section{Institut français d'Indologie}

A French Institute for Indology was created at Pondicherry (South India) in I955, in agreement with the Government of India, when the former French Settlement was handed over to India. It is placed under the administrative and financial control of the French General Direction of Cultural and Technical Affairs, Ministry of Foreign Affairs. The founder and director is Jean FILLIOZAT, who spends sev- 
eral months each year at Pondicherry. There is a staff of French and Indian scholars, and a library which is already quite considerable and particularly rich in manuscripts concerning South India. The orientation of the Institute is towards research on the history, archaeology, languages, literatures, religions, and philosophies of India, with emphasis on the relations of Indian culture with the cultures of Indochina and Indonesia; it has undertaken an archaeological survey of the region around Pondicherry. A collection of "Publications" has been launched (9 volumes 1956-58).

\section{Délégation archéologique française en Afghanistan}

The French Archaeological Delegation in Afghanistan, created in 1922 by agreement between the French and Afghan governments, is controlled and financed by the Commission for Excavations and Archaeological Missions (Commission des Fouilles et Missions archéologiques) of the French Ministry of Foreign Affairs. It has brought important contributions to the knowledge of the northwestern borderlands of ancient India. The founder and first director was Alfred FOUCHER (I922-45); he was succeded by Daniel SCHLUMBERGER (since 1945), who is now excavating in ancient Bactriana; field directors, well-known for their excavations in ancient Kapiśa and elsewhere, have been Joseph HACKIN (r925-40) and Roman GHIRSHMAN (I94I-43).

To it has been attached for several years the French Archaeological Mission in India, headed by J. M. CASAL, who after working in the region of Pondicherry during $1946-50$ has been pursuing since then excavations in a "Pre-Indus culture" site at Mundigak (Afghanistan), and is now going to undertake "Indus culture" excavations in Pakistan.

The French Archaeological Delegation in Afghanistan publishes a collection of "Memoirs," profusely illustrated (I5 volumes 1928-54).

\section{Publications}

In addition to the periodicals and collections mentioned above under the various institutions responsible for them, mention should be made of the Troung Pao, Archives concernant l'histoire, les langues, la géographie, l'ethnographie et les arts de $l$ 'Asie Orientale, which is now in its sixty-ninth year ( 56 volumes). Published by E. J. Brill at Leiden, it was founded in 1890 by a French historian of China, Henri CORDIER, and a Dutch sinologist, Gustav SCHLEGEL, and its direction has been since then either both French and Dutch or purely French (directors: Henri CORDIER and Gustav SCHLEGEL, I890-1903; Henri CORDIER and Edouard CHAVANNES, I904-I8; Henri CORDIER and Paul PELLIOT, I920-25; Paul PELLIOT, 1925-35; Paul PELLIOT and J. J. L. DUYVENDAK, 1936-45; J. J. L. DUYVENDAK and Paul DEMIEVILLE, I945-54; Paul DEMIÉVILLE, I955-56; Paul DEMIEVILLE and A. F. P. HULSEWE, since 1957). It is at present subsidized both by the French National Center for Scientific Research and the Dutch Organization for Pure Scientific Research. The language is French, but articles in other Western languages are also accepted. Annexed to it are a series of "Supplements" (6 volumes 1 894-1944) and a collection of "Monographs" (3 volumes r950-54). A General Index of the first 47 volumes of the T'oung Pao (1890-1944) was published in 1953.

The Bibliographical Review of Sinology (Revue bibliographique de sinologie), launched by an international staff of contributors following a wish expressed by the 8th International Congress of Junior Sinologues in 1955 , is published by MOUTON 
\& Co. at The Hague under the auspices of Section 6 of the Practical School for Higher Studies (the first volume, covering the year 1955, came out in 1957).

Since the last war a long series of weekly radio talks on China, India, Japan, and Tibet has been included by the "Radiodiffusion Française" in its cultural program. The talks on China, in which the entire school of French sinologists has taken part, are in course of publication ("Aspects de la Chine," 3 volumes, now in press); the talks on India will also be published.

\section{List of Theses concerning East Asia completed in France $194^{6-58}$}

UP $=$ Université de Paris

$E P H E=$ Ecole pratique des Hautes Etudes (the number indicates the Section)

$\mathrm{EL}=$ Ecole du Louvre

Lille $=$ Université de Lille

Lyon $=$ Université de Lyon

$\mathrm{TP}=$ Thèse principale de Doctorat ès Lettres

$\mathrm{TC}=$ Thèse complémentaire de Doctorat ès Lettres

$\mathrm{TU}=$ Thèse de Doctorat d'Université

1946

Jean FILLIOZAT, Les sources anciennes de la médecine indienne, UP (TP); Fragments de textes koutchéens de médecine et de magie, UP (TC)

Jeannine AUBOYER, Le trône et son symbolisme dans l'Inde, EPHE, 4

Marie-Thérèse DE MALLMANN, Introduction à l'étude d'Avalokiteśvara, EPHE, 4

Anne-Marie ESNOUL, La bhakti brâhmanique, EPHE, 5

Odette VIENNOT, Le culte de l'arbre dans l'iconographie indienne, EL

1947

Charles HAGUENAUER, Introduction à l'étude des origines de la civilisation japonaise: la préhistoire insulaire jusque vers $25^{\circ} \mathrm{p}$. C., UP (TP); Introduction à l'étude de la langue japonaise, UP (TC)

Jean MONSTERLEET, Littérature chinoise contemporaine: écrivains témoins de leur temps, UP (TP); Pa-kin, "Brumes," UP (TC)

Roman GHIRSHMAN, Begram: recherches sur l'histoire des Kouchans, UP (TP); Les Chionites-Hephtalites, UP (TC)

André BAREAU, La notion d'asamskẹta dans l'Abhidharma, EPHE, 4

1948

Liliane SILBURN, Instant et cause: le discontinu dans la pensée philosophique de l'Inde, UP (TP); Le Paramärthasära d'Abhinavagupta, UP (TC)

Jacques A. DURR, Morphologie du verbe tibétain, UP (TP); Deux traités grammaticaux tibétains, UP (TC)

Gustave LEVY, La vie familiale et sociale des Indiens Namlik-Wara, UP (TC)

Subhadra JHA, Vidyāpati et ses oeuvres lyriques, UP (TU)

LIN Li-wei, Wang Kouo-wei (1878-rg27), sa vie et son oeuvre, UP (TU)

TCHEN Ysia [TCH'EN Yi-hia], La musique chinoise en France au XVIII ${ }^{e}$ siècle, UP (TU)

WEI Ying-pang, La politique chinoise en Mongolie et au Tibet de I871 à 1922, UP (TU)

TRÂN-cuu-Chân, Etude critique du Kim-van-Kiêu, poème national du Vietnam, UP (TU)

Jacques GERNET, Entretiens de Chen-houei, EPHE, 4

Henri DEYDIER, Contribution à l'étude de l'art du Gandhāra, EPHE, 4 
Liliane SILBURN, La Śvetäśvatara Upanișad, EPHE, 5

Solange BERNARD, Le lion dans les arts de l'Inde, EL.

M. G. BOURDA, Etude du Bodhisattva Maitreya: son iconographie dans l'Inde propre et dans l'Inde extérieure, EL

Madeleine DAVID, Les jades de la Chine ancienne au Musée Guimet, EL.

Odette MONOD, Le guide-catalogue du Musée Guimet et le problème général des guidescatalogues, EL

M. WELTÉ, Le mobilier chinois de l'époque Han à l'époque T'ang, EL

I 949

Louis MALLERET, Récentes découvertes concernant l'archéologie du Fou-nan, UP (TP); Essai sur l'évolution du delta du Mékong, UP (TC)

LE-van-Ly, Le parler vietnamien, structure phonologique et morphologie fonctionnelle, UP (TP); Traduction et commentaire du poème vietnamien Quan-âm thê-kinh truyên, UP (TC)

Marie-Antoine BOURDON, La Compagnie de Jésus et le Japon, UP (TP)

Ramesh MITRA, Le déclin du bouddhisme dans l'Inde à partir du VII e siècle, UP (TU)

Jagban BALBIR, Le Siśupālavadha, une étude, UP (TU)

François TSU Zu-tche, La vie des pêcheurs du bas Yang Tse, UP (TU)

Odette VIENNOT, L'arbre dans les croyances et les rites de l'Inde, d'après les textes et les documents figurés, EPHE, 5

J. M. CASAL, L'Inde et l'Occident aux environs de l'ère chrétienne: les fouilles de Virapatnam; méthodes de fouille et résultats, EL.

M. GUILLOT, Contribution à l'étude chronologique des statuettes funéraires chinoises, EL

M. T. LE PAGE, L'art monétaire des royaumes grecs de Bactriane: essai sur l'interprétation de la symbolique gréco-orientale du III ${ }^{\mathrm{e}}$ au Ier siècle av. J.-C., EL

1950

Charlotte VAUDEVILLE, Les sources et la composition du Rāmāyaṇa de Tulsi-Das, UP

(TP); Traduction de l'Ayodhyäkanda du Rāmāyaṇa de Tulsi-Das, UP (TC)

Narayan KALELKAR, La secte Mānbhav, UP (TU)

TONG Ling-tch'ouang, La politique française dans la guerre des Taiping, UP (TU)

Edouard THEYSSET, L'essor du mouvement ouvrier au Japon (1945-1948), UP (TU)

I95I

André BAREAU, L'absolu en philosophie bouddhique: évolution de la notion d'asamskrta, UP (TP); Dhammasangani, traduction annotée, UP (TU)

Ananda SALGADO, Les castes dans les Brāhmaṇas, UP (TU)

Mahabaduge JAYASURIYA, Etudes linguistiques sur les Brāhmaṇas, UP (TU)

KOU Pao-koh [KOU Pao-kou], Houei Che et Kong-souen Long, sophistes chinois, UP (TU)

A. BHATTACHARYA, La voie de la libération par la connaissance dans le Bhāgavata Puräna, Lille (TU)

r952

Tara DASH, L'Inde et les écrivains français de I870 à I9I 4 d'après la Revue des Deux Mondes, UP (TP); La connaissance de l'Inde en France de I870 à 1914, essai de bibliographie critique, UP (TC)

Vinayak HATALKAR, Les relations de la France avec le royaume de Mysore, UP (TU) CHOW Yih-ching [TCHEOU Yi-k'ing], La philosophie morale de Tcheou Touen-yi: aux origines du néo-confucianisme, UP (TU) 
KAO Chung-ju [KAO Tchong-jou], Le mouvement intellectuel en Chine et son rôle dans la Révolution Chinoise entre 1898 et 1937 , UP (TU)

Robert FAST, Le coton en Chine, UP (TU)

CHÂU Lang, La politique de Lanessan en Indochine, UP (TU)

Ginette TERRAL, Samuddaghosajātaka, conte pāli tiré du Pañãäsajātaka, EPHE, 4

Jean BOISSELIER, La statuette khmère et son évolution, EL

Geneviève CASAL, Les cimetières d'urnes funéraires de Mouttra-Pallon, résultats des fouilles de $195^{\circ}$ dans l'Inde, EL

I953

Pierre DUPONT, L'archéologie indo-mône et les fouilles de Nakhon-Patham, UP (TP); La version mône du Näradajātakă UP (TC)

Banecha MINETRAKINETRA, Les religions de la Thailande, UP (TU)

Michel SOYMIE, Le Lo-feou chan, essai de monographie d'une montagne, EPHE, 5

Mme LAVAYSSIËE, Remarques sur seize estampes illustrant la vie de Confucius et conservées au Cabinet des Estampes de la Bibliothèque Nationale, EL

1954

James HAMILTON, Les Chinois et les Ouighours sous les Cinq Dynasties, UP (TU) Galen Eugene SARGENT, Le bouddhisme chez Tchou Hi (Ir30-1200), UP (TU)

SIBUNRUANG Jit-Kasem, Coutumes de la vie siamoise d'après le poème populaire Khun chang khun phen, UP (TU)

M. GUNASINGHE, La technique dans la peinture indienne, d'après les textes de Silpa, UP (TU)

HOANG-gia-Linh, Tagore patriote indien et citoyen du monde, Lille (TU)

PAI Bong Yong, Les croyances populaires en Corée, Lyon (TU) [year uncertain]

Georges CONDOMINAS, Chronique d'ethnographie religieuse d'un village Mnong Gar, EPHE, 5

Bernadette TUBINI, Documents relatifs au culte du soleil dans l'Inde médiévale, EPHE, 4

Jean-Paul ROUX, Tängri, essai sur le Ciel-Dieu chez les peuples altaïques, EPHE, 4

Krishna GAIROLA, Evolution du pürna-ghața (vase d'abondance) dans l'Inde et dans l'Inde extérieure, EL

1955

NGUYEN-khac-Hoach, Le roman vietnamien aux $\mathrm{XVIII}^{\mathrm{e}}$ et $\mathrm{XIX}$ siècles, UP (TP); Contribution à l'étude critique et bibliographie des principaux romans vietnamiens aux $\mathrm{XVIII}^{\mathrm{e}}$ et XIX ${ }^{\mathrm{e}}$ siècles, UP (TC)

Lokenath BHATTACHARYA, Deux textes techniques de magie de l'Inde tardive, UP (TU)

Govind CHANDRA, Parures et bijoux dans l'Inde protohistorique, UP (TU)

Rasik JOSHI, Le rituel de la dévotion kṛ̣naïte, UP (TU)

Kunda SATHE, La divination par les rêves dans l'Inde, UP (TU)

Priyabala SHAH, L'iconographie de Sūrya d'après les Purāṇa, UP (TU)

CHOW Pin-kien, Leibniz et la pensée religieuse en Chine, d'après Novissima sinica et les correspondances, UP (TU)

BUI-thê-Phuc, Le Têt, fête du Nouvel An vietnamien, UP (TU)

Ladda SIMITHINANT, Les influences étrangères sur la littérature siamoise à la fin du $\mathrm{XVIII}^{\mathrm{e}}$ et au milieu du XIX ${ }^{\mathrm{e}}$ siècle, UP (TU)

Pensri SUVANIJ, Les relations entre la France et la Thailande au XIX siècle, d'après les archives des Affaires Etrangères, UP (TU)

Mohamad RASJIDI, L'évolution de l'Islam en Indonésie (Java), ou considération critique du livre Tjentini, UP (TU) 
Madeleine BIARDEAU, Le Tattvabindu de Vācaspati Miśra, EPHE, 5

Frédéric BISCHOFF, Contribution à l'étude des divinités mineures du bouddhisme tantrique: Ärya-Mahābala-nāma-mahāyāna-sūtra, tibétain (manuscrits de Touen-houang) et chinois, EPHE, 4

$$
1956
$$

Jacques GERNET, Les aspects économiques du bouddhisme dans la société chinoise du $\mathrm{V}^{\mathrm{e}}$ au $\mathrm{X}^{\mathrm{e}}$ siècle, UP (TP); Les contrats de vente de Touen-houang, UP (TC)

Eveline POREE-MASPERO, Etude sur les rites agraires des Cambodgiens, UP (TP); Le Krông Palî et les rites de la maison, UP (TC)

Donald HOLZMAN, La vie et la pensée de Hi K'ang (223-262 ap. J.-C.), UP (TU)

Charles COMMEAUX, De K'ang-hi à K'ien-long, l'âge d'or des 'Ts'ing (1662-1796), Lyon (TU)

D. S. RUEGG, Contributions à l'histoire de la philosophie grammaticale indienne, EPHE, 4

1957

Manfred PORKERT, Biographie canonique du Saint du Yang Pourpre (Tseu-yang tchenjen nei-tchouan), UP (TU)

HU Liang-chen, La société Lolo des Ta-leang chan au sud-ouest de la province de Sseutch'ouan, UP (TU)

Louis WEI, L'ouverture des cinq ports au commerce étranger et la liberté religieuse en Chine ( $1842-1856)$, UP (TU)

WOU Tchong-hong, La vie et l'oeuvre de Tcheng Pan-k'iao (1693-1765), UP (TU)

DEV RAJ, L'esclavage dans l'Inde ancienne, d'après les textes pālis et sanskrits, UP (TU)

Lêk THANPRASEURT, Les fêtes du Trut Sankrant au Siam, UP (TU)

Suzanne VREEDE, L'émancipation de la femme indonésienne, UP (TU)

D. A. MACDONALD, Etudes sur le mandala dans le Mañjuśrīmülakalpa, EPHE, 4

Suzanne SIAUVE, La voie vers la connaissance de Dieu (brahma-jijñāsa) selon le Dvaita Vedānta, EPHE, 5

1958

Nicole VANDIER-NICOLAS, Art et sagesse en Chine: Mi Fou (105I-II07), peintre et connaisseur d'art, dans la perspective de l'esthétique des lettrés, UP (TP); La peinture chinoise: traduction et commentaire de l' "Histoire de la peinture" (Houa-che) de Mi Fou, UP (TC)

Munishwar JHA, La langue Māgadhī, UP (TU)

Manohar SARDESSAI, L'image de l'Inde en France au XVIII siècle, UP (TU)

Vanni CHANDRADIBAYA, La satire dans la littérature siamoise, UP (TU)

TRÂN-van-Khê, La musique vietnamienne traditionnelle, UP (TU)

Mireille BENISTI, Le stūpa figuré dans les monuments de l'Inde ancienne, EPHE, 4

In universities and at EPHE, the rule is that all theses should be printed before the degree or diploma is granted. In fact, owing to difficulties following the last war, only a few of the theses listed above were printed before presentation; most of them have been published since presentation, sometimes under slightly different titles; about one third remain unpublished.

\section{Bibliography}

Université de Paris, Livret de l'étudiant, yearly.

Annuaire du College de France, yearly.

Société Asiatique, Le livre du centenaire (I 822-1922), Paris, 1922.

Liure jubilaire composé à l'occasion du $4^{\circ}$ centenaire du Collège de France, Paris, 1933.

La science française, nouvelle édition, Paris, 1933. 
Cent-cinquantenaire de l'Ecole des Langues orientales, Paris, 1948.

Louis MALLERET, "Aperçu d'un demi-siècle de travaux scientifiques à l'Ecole Française d'Extrême-Orient," France-Asie (Saigon), Oct.-Dec. 1956.

Yves HERVOUET, Les bibliothèques chinoises d'Europe occidentale, Mélanges publiés par l'Institut des Hautes Etudes chinoises, I, Paris, 1957.

The author of this notice wishes to thank his colleagues who have helped him to correct or complete it.

\section{COMMUNICATIONS}

The Editor, The Journal of Asian Studies

\section{Dear Sir:}

Professor Edward H. Schafer has contributed two interesting and thought-provoking letters to the May $195^{8}$ issue of the Journal (pp. 509 and 512). He argues some meaningful questions in a forceful manner, and I find myself sympathetic to many of his points of view. However, in the second of these two letters, apparently in excess of enthusiasm for good causes, he has made some rather drastic charges, and has too hastily pounced on some examples which do not sustain even his best arguments. Since they refer to a book review of mine recently published in the Journal, I request an opportunity to reply. The evaluation of the book which I reviewed is not the real issue, either in Professor Schafer's remarks or in my reply, hence I shall not refer to it again here.

Professor Schafer, in comparing word forms of "Classical" and "Mandarin" Chinese (his terms), criticizes me for suggesting that certain multiple-character expressions in the "Classical" should be understood as words. In this he states that I am being "anachronistic," i.e., am asking that Classical Chinese be treated as if it were Mandarin, thereby "yielding to the temptation to simplify his [i.e., a translator's] task by the application of the unscholarly principles of 'Mandarinization' and 'etiolation.'" Strong words, indeed! Professor Schafer appears to mean that words like shou-shih (jewelry) and shu-chi (books) -both are his examples-belong solely to modern "Mandarin" and could appear in literary Chinese only when a modern Mandarin-speaking writer of literary Chinese unconsciously borrowed it from his speech and used it in his writing, where by stricter standards it should be considered out of place. "Mandarin" is a dialect of modern spoken Chinese; shu-chi and shou-shih as "words" in the sense given above are very old. Even if Mr. Schafer avoids that difficulty by making "Mandarin" mean the spoken Chinese of any place or period, he still is in difficulty with regard to what his remarks imply about the relationship between the literary and spoken languages. Multiple-character expressions like these did not all necessarily originate in the spoken language and move into the literary. His line of argument appears to me to show inadequate regard for the long development of both the literary and the spoken languages. Particularly in the literary Chinese of somewhat informal collections of notes and sketches such as the fourteenth-century text in question, but in fact in almost all literary Chinese of the last two millennia or more, the influence of the spoken idiom is to be discerned. Both literary and spoken Chinese have developed much in the long period between the earliest literary monuments and the present, through interrelated processes of development showing mutual influences throughout. Many general nouns such as shu-chi and shou-shih are to be found in fourteenth-century 